Biorheology Vol. 15, pp. 375-386.

Pergamon Press Ltd. 1978. Printed in Great Britain

\title{
CONVOCATION ADDRESS
}

\section{Prospects of Biorheology in the Future}

\author{
Alfred L. Copley
}

Laboratory of Biorheology, Polytechnic Institute of New York Brooklyn, NY 11201, U.S.A.

\section{Introduction}

I feel greatly honored to have been asked by my good friend Bert Fung, Chairman of this our Third International Congress of Biorheology, to give the Convocation Address on Prospects of Biorheology in the Future.

As anything alive has a history, so has our science of biorheology. I shall, therefore, first give briefly a historical account and then present an outline of the future prospects of biorheology.

\section{Brief History and Organizational Outlook of Biorheology}

Biorheology as an organized science had its beginning in Holland at Scheveningen when the First International Congress on Rheology was held in 1948 (1). If one likes to set milestones on the road of biorheology and mark them with brief inscriptions, one may read on the first milestone: "1948 S cheveningen, Holland". In 1947 I was invited by the organizing committee of this Congress to give a general lecture on "Rheological Problems in Biology" (2). G.W. Scott Blair gave a general lecture on psychorheology (3), and a paper on the interaction of myosin and actin was presented by W.T. Astbury $(4)$. There were at least five additional communications of biological interest by Maurice Joly (5), Karl Weissenberg (6,7), Hans Kuhn (8), A. De Waele and E.W.J. Mardles (9), although not dealing with biological problems. Thus, several presentations before this Congress thirty years ago dealt with biorheology or with findings applicable to it.

In my overview (2), which was the first of its kind, I stated the following: "It is necessary to recognize the significance of rheological problems in the future of the biological sciences. These problems may develop eventually in a science branch of its own for which I should like to propose for the sake of convenience the term 'bio-rheology'. It may be predicted that bio-rheological inquiries into the nature and origin of life will grow in scope and volume" (2).

In the overview I referred to the biorheological literature which up to that time dealt mainly with the rheology of protoplasma and the rheology of blood. It was three years later, when I introduced the term "hemorheology" for the rheology of blood and of the blood vessel wall, i.e. of structures with which blood or its components come into direct contact. This was in 1951 in a lecture before the Society of Rheology at the 25 th Anniversary Meeting of the American Institute of Physics, held in Chicago (10).

At Scheveningen, I emphasized that "the study of rheological problems in biology is still at the preliminary stage". It was an attempt "to gather a few rheological data which have accumulated so far in the biological literature and to present rheological phenomena with which the experimental biologists are faced". I was "convinced that rheology will play a very important role in the biological sciences including medicine of tomorrow", and concluded that "a combination of the sciences of rheology and biology is bound to serve the well-being of our species".

- Perhaps I should stop just here, as I believe that the above cited insights, marking the first milestone of biorheology, are as valid today as they were thirty years ago. 
Since Scheveningen $\mathrm{mark}$ the first milestone in the history of our science, the subsequent ones mark international conferences or congresses, at which special sessions or/and symposia on biorheology were held, and in particular those conferences or congresses dedicated entirely to biorheology or to one of its branches, such as hemorheology.

It should be emphasized that each of the following International Congresses on Rheology included always papers and, later, sessions on biorheology. Thus, at the second International Congress, held in Oxford in 1953, one General Lecture and three Sectional Papers dealt with biorheological subjects (11).

A colloquium on rheological problems in biology, which took place in 1950 in Lund, Sweden, dealt with different fields of animal, plant and cellular biorheology. Several papers presented at this colloquium are included in Frey-Wyssling's book, which contains also the abstracts and discussions of the presentations at this meeting $(12,13)$.

In 1958 the meeting "Flow of Blood in Relation to the Vessel Wall", which I organized, was held at the Charing Cross Hospital Medical School of the University of London, to which about one hundred men and women came $(11,14)$. This was a highly successful meeting, as it also led, following discussions between R.G. Macfarlane, F.R.S., F.J.W. Roughton, F.R.S., G.W. Scott Blair and myself, to a conference on biorheology in oxford in the following year.

During the Third International Congress on Rheology, held in Bad Oeynhausen, Federal Republic of Germany, Scott Blair reported that "not only were there several biological contributions but a skeleton organization was set up to investigate the possibilities of developing further this branch of our science" (11).

The above mentioned conference on biorheology, entitled "Flow Properties of Blood and other Biological Systems", was held in 1959 at the University Laboratory of Physiology in Oxford, England, under the auspices of the Colloid and Biophysics Committee of the Faraday Society and the British Society of Rheology $(11,15)$. At that time the founding of an international society of biorheology was further discussed.

I should like to commend the merits of Mr. Robert Maxwell, Founder and Publisher of Pergamon Press, in sponsoring our new science. Early in 1959 he phoned me in London and proposed the publication of the Proceedings of our Conference which was to be held on 23 and 24 september of that year in Oxford. Our organizing committee, at a meeting in Gwyn Macfarlane's office in Oxford, accepted his offer which led to the publication of "Flow Properties of Blood and Other Biological Systems" in 1960 (11). After our Conference in September, Mr. Maxwell got in touch with me again, as he intended to publish an international journal of biorheology. This led to the publication of "Biorheology. An International Journal" by Pergamon Press with me and George Scott Blair as Founders and Co-Editors-in-Chief (16). Later, in 1966, Mr. Maxwell showed again his keen interest in our science in publishing the Proceedings of the First International Conference on Hemorheology held that year at the University of Iceland. The book, beautifully presented on 871 pages, was published in 1968 (17). In my Joint Inaugural Address on September 4, 1972, at the Sixth International Congress on Rheology and the First. International Congress of Biorheology at Lyon, France, I emphasized that with the publication of our journal Biorheology our science became more known and that the journal "continues to serve as a stimulus to research in different branches of biorheology, including hemorheology" (IE). This attainment is in great part due to the encouragement by $\mathrm{Mr}$. Robert Maxwell and his unflazging interest in our science. I should like to take this opportunity to express the gratitude of the practitioners of biorheology to Mr. Maxwell, also in my former activity as President of our Society $(19,20)$ and the subsequent one as its first Past President, whose term ends with this Congress.

In 1963 a Symposium on Biorheology, which I organized as part of the 4 . International Congress on Rheology, was held in Providence, Rhode Island (21). After its closing session during a round table discussion on hemorheology which followed, my friend Hellmut Hartert suggested that formal steps should be taken to organize an International Society of Biorheology, with me as its first President (22). Although I considered such a venture to be premature at that time (22), I took the initiative to organize the First International Conference on Hemorheology, sponsored by the University of Iceland, which, took place from July 10 to 16, 1966 in Reykjavik: It was Nina Tryggvadottir, 
my late wife, who suggested her native country for this conference and made the initial step in introducing me to the Rector of the University, Professor Armann Snaevarr, who supported enthusiastically the plan of this conference. I was aided in the organization of this international meeting by George Bugliarello and Roy L. Whitmore as secretaries, Roe E. Wells as treasurer and by A.C. Burton, L.E. Gelin, M. Joly, H. Hartert, S. Oka, G.W. Scott Blair and A. Silberberg. All of us formed the Executive Organizing Committee together with a local committee, headed by Professor Olafur Bjarnason, President of the Icelandic Medical Association (17).

The first Poiseuille Gold Medal was awarded to Robin Fåhraeus at the Conference in Reykjavik, during which the International Society of Hemorheology was founded (17). It was decided that future international conferences should be an activity of the Society and take place every three years in different countries under the auspices of a leading university or research institution. The second International Conference on Hemorheology took place in 1969 under the auspices of the University of Heidelberg, with Hellmut Hartert as its President (23). During this time it was decided to widen the scope of the Society and include all fields of biorheology, which led to the change of the Society's name to that of the International Society of Biorheology. Soon after this Conference our Society became in 1969 an Affiliated Commission of the International Union of Pure and Applied Biophysics (IUPAB). This recognition came about due to the efforts of our dear friend, the late Aharon KatzirKatchalsky, who at that time was the President of the IUPAB. He was a charter member of our Society and an Editor of our Journal since its inception (28). We shall always remember Aharon's great enthusiasm for biorheology and its future.

Our First International Congress of Biorheology, of which I was the President, was, as said above, jointly convened with the Sixth International Congress on Rheology (24). The two congresses were held in 1972 in Lyon, France, under the auspices of the Université Claude Bernard and the Institut National des Sciences Appliquées. The Second International Congress of Biorheology with Alex Silberberg as its President took place from 29 December 1974 to January 7,1975 under the auspices of the Weizmann Institute of Science in Rehovot, Israe1 (25).

With volume 9, Biorheology became the Official Journal of our Society in 1972 and, with volume 11, a bimonthly publication in 1974 .

There are, as I mentioned, several milestones in the history of biorheology as an organized science, which are given in Table 1 .

TABLE 1

\section{MILESTONES IN THE HISTORY OF BIORHEOLOGY AS AN ORGANIZED SCIENCE}

$\begin{array}{ll}1948 & \text { Scheveningen, Holland } \\ 1950 & \text { Lund, Sweden } \\ 1953 & \text { Oxford, England } \\ 1958 & \text { London, England and Bad Oeynhausen, Federal Republic } \\ & \\ 1959 & \text { Oxford and London, England } \\ 1962 & \text { New York, NY, USA, Shinfield and Oxford, England } \\ 1963 & \text { Providence, RI, USA } \\ 1966 & \text { Reykjavik, Iceland } \\ 1969 & \text { Heidelberg, Federal Republic of Germany } \\ 1972 & \text { Lyon, France } \\ 1975 & \text { Rehovot, Israel } \\ 1978 & \text { La Jolla, CA, USA }\end{array}$

We all are looking forward to the next marking: 1981 - Tokyo, Japan. Undoubtedly, there will be many new milestones in this century and they will become numerous beginning with the year 2000. 
Biorheology as an organized science is no longer a dream as it was in 1948. It is here to stay and to grow. You and others have built this science which proudly and vigorously takes its place next to the other sciences and makes more meaningful the 'vita activa' of each of us, engaged in biorheological research.

In the beginning of this year, the first national society of biorheology with about 200 members was founded in Japan. There will also be a need for national societies of biorheology or of its branches in other countries, as there will continue to be groups, internationally and nationally, which will go on holding scientific conferences in different fields of biorheology.

Many among you will know that during the past decade our Society was the co-sponsor of several conferences on biorheology or its branches, organized by the international congresses of rheology, biophysics, physiology, hematology, and microcirculation, as well as by national congresses, such as that of the American Institute of Chemical Engineers (26). Such joint efforts, in which our Society is a partner, should be encouraged by everyone of us, as they open ways to acquaint our colleagues in the other sciences what biorheology or any of its branches or fields are all about and what biorheology can do towards the advancement of knowledge.

There were several other important events which are among the milestones of our science. They too served our science and will continue to do so, since they concern publications of the proceedings of other biorheological conferences.

In the beginning of this year Biorheology has become a journal for rapid publication, which necessitated a new editorial policy with twelve editors serving up to six years (27). It is my hope that our journal will become a monthly publication as soon as possible. The rapid dissemination of new research findings and original ideas in contributions of high scientific merit will serve a much wider reading public among fellow scientists working in othex disciplines, stimulate new research and attract contributions of great competence and high originality.

A special event in the history of our science is the establishment of the Poiseuille Gold Medal Award whose first recipient was Robin Fahraeus in 1966. To our great joy, our friend Maurice Joly will become today, after this Convocation, its fifth awardee.

\section{Biorheology - A Major Life Science in the Future}

Biorheology will play an ever increasing major role in the solution of numerous problems in the life sciences and in the practice of medicine. This involvement of biorheology will open up vast new perspectives towards the advancement of science. The biorheological exploration of life processes is of great significance to the future of the biological sciences.

Biorheological experimentation and treatments are bound to be more and more included in multidisciplinary research regarding many problems, e.g., in the biomedical sciences. Atherosclerosis is an example of multidisciplinary approach, in which hemorheological studies play an important role. In recent years experimental research on atherogenesis included hemorheological considerations and studies (29-35).

A new theory of early atheroma formation was presented by me two months ago at a symposium on heart and brain infarcts, organized by the Max-P1anckInstitut für Hirnforschung, Cologne (30). Two pathways of uptake of low density 1ipoprotein or $\beta$-lipoprotein were proposed by me, one of which is the adsorption of this lipoprotein to the endoendothelial fibrin lining ( 30,36 , 37). The affinity of cholesterol carrying lipoprotein to fibrin was already suggested by me in two Letters to The Lancet in 1957 (36,37) without there being the need for an injury to the vessel wall. The other pathway concerns the initial thrombus formation by the clotting of fibrinogen without thrombin participation $(38,39)$, a growth process, layer upon layer, of fibrinogen and the formation of a gel. Copley and King (40) found extremely low torque values in the rigidity of systems of highly purified fibrinogen and $\beta$-lipoprotein surface layers. This is shown also in Fig. 1, without pre-shear and after shearing for 1 min at $1000 \mathrm{sec}^{-1}$. 


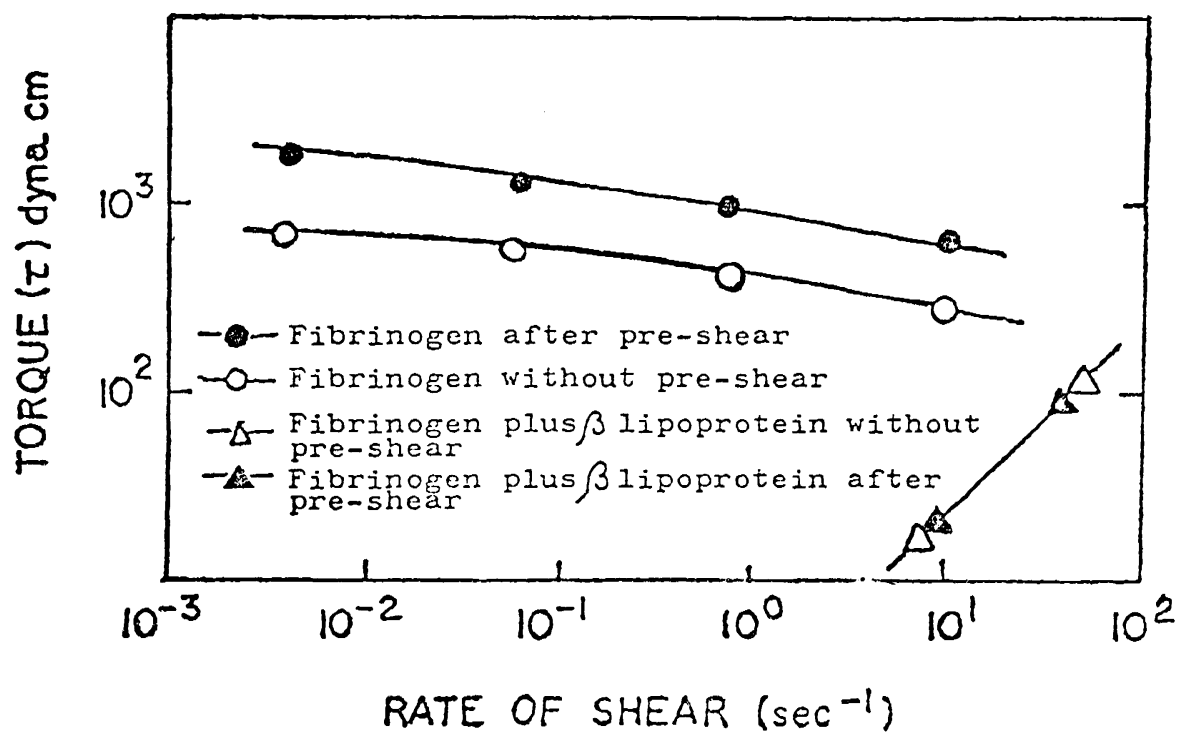

Fig. 1

Comparisons of torque values from surface layers between 0.4 per cent highly purified fibrinogen (100 per cent clottability) without and with the addition of 0.25 per cent highly purified $\beta$-lipoprotein without preshear and after shearing at $1000 \mathrm{sec}^{-1}$ for 3 min.

CONCEPT OF EARLY DEVELOPMENT OF ATHEROMA (COPLEY, 1978)

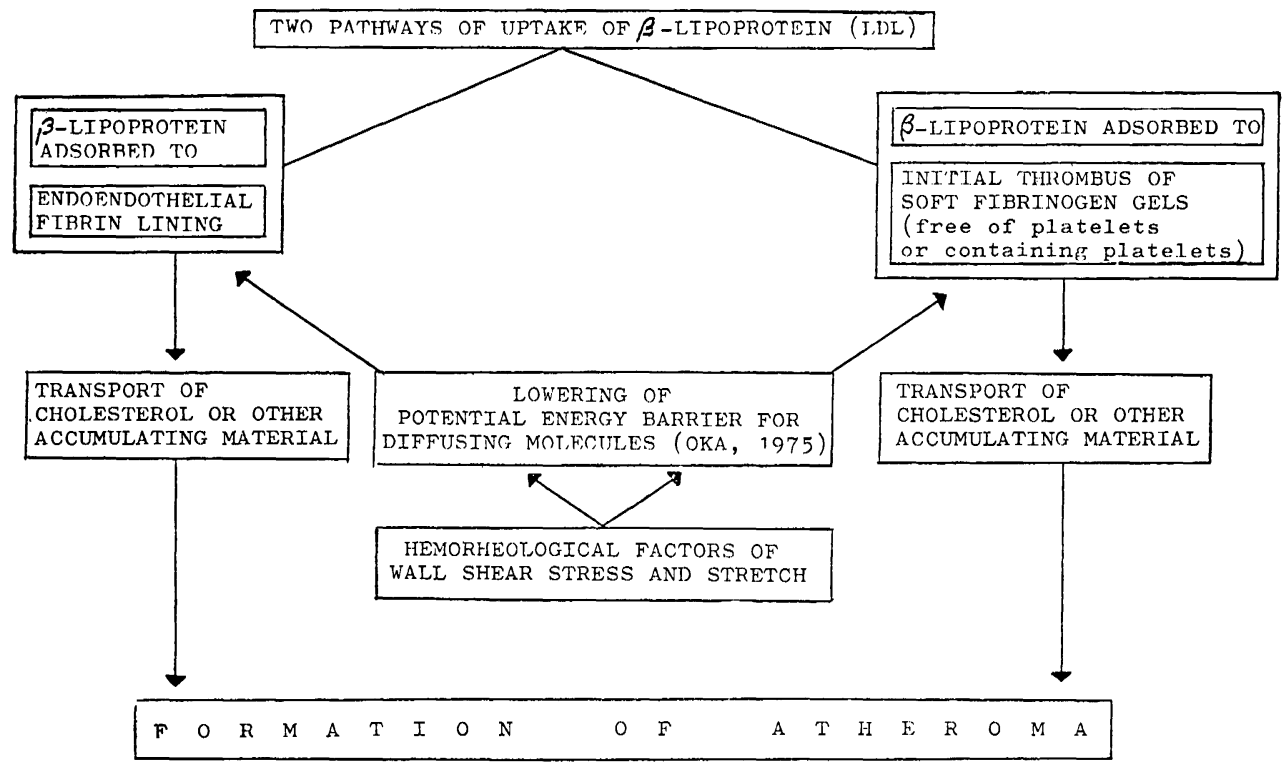

Fig. 2

Schematic diagram of the author's theory on the genesis of atheroma formation. 
Our findings suggest that the $\beta$-1ipoprotein interferes with the bonding of the fibrinogen molecules, resulting in very weak structures of fibrinogen layers and of gels, if formed, which will thus be very soft and fragile. Such weak or fragile structures of fibrinogen gels are important for the consideration of the newly proposed second pathway (diagrammatically shown in Fig. $2)$, since they might permit increased uptake of $\beta$-lipoprotein carrying cholesterol or/and other accumulating material. In both pathways, the theory is also based on the recent surface chemical studies by Miller et al (41) concerning the adsorption of lipoproteins on proteinaceous surface and their desorption from it. According to these authors lipoprotein molecules can be desorbed readily and may maintain transient contact with the proteinaceous blood vessel surfaces which I consider to be mainly fibrin or/and fibrinogen. Their metabolic digestion, leaving the lipids behind, would then result in the formation of fatty streaks, lesions and atheromas.

My theory of atheroma formation (Fig.2) includes the theoretical approach to atherogenesis by oka (29) in that prior to or simultaneous with these processes of adsorption and desorption of $\beta$-lipoprotein and other accumulating material to fibrin(ogen) surface, the hemorheological factors of wall shear stress and stretch, which he proposed two years ago, come into play. In Oka's approach, applying polymer physics and the theory of rate processes, which he is also presenting at this Congress, the lowering of the potential energy barrier for diffusing molecules contributes to the formation of atheroma.

Although clinical hemorheology has been practiced since several decades more and more both diagnostically, such as the erythrocyte sedimentation rate, the viscosity of blood systems, and Hartert's thrombelastography, and therapeutically, e.g., by hemodilution, it is anticipated that clinical hemorheology will be greatly expanded to include many new hemorheological techniques and treatments.

Many biorheological tests and treatments, other than hemorheological ones, will be introduced in the practice of medicine and surgery. Clinical biorheology will play an important role in more successful clinical management including therapy and in prophylactic measures. It will also be applied towards better birth control and to more effective aid to the aged. Clinical biorheology will become a major discipline and taught in medical, dental and veterinary schools. It will also have a great impact on space bio-medicine and many biorheological tests will be carried out near zero gravity in spacelab modules and in future space colonies.

Advancement of knowledge in biorheology will likewise be applied, among others, to genetics, the differentiation of cells, embryology and growth processes including cancer. However, biorheology will not be limited to problems relating to life processes in mammals and other animals, but will be extended to microorganisms including viruses and viroids, and, in particular, to plant organisms. Here I should like to refer in particular to the work by Kamiya and his pupils on the rheology of plant cells and the recent review on botanical biorheology by Spanner in the book by George scott Blair "An Introduction to Biorheology" (42). This book contains other most useful information.

It is almost paradoxical that the flow of a non-biological simple fluid, such as water (43), was first studied by Poiseuille after he made, about 143 years ago, his hemorheological observations of the very complex microcirculation in animals (44). This led to what is well known as the Poiseuille law. There will be a growing number of stimuli from biorheological researches in non-biological scientific and technological areas. There will be also an augmentation of new theoretical biorheological approaches, which will be advanced for many complex biological manifestations and processes. These theoretical concepts will become available for application to medical, biological, other scientific and technological disciplines.

As in many of the natural sciences, the reported findings will tend to move from descriptive figures towards analytical equations. For instance, the rheological properties of blood have been frequently reported during the last decade as plots of the apparent viscosity as a function of shear rate. In the future, rheological equations to represent the plots will be used more and more. Such equations may promise to provide a broader characterization of flow properties of blood, such as thixotropy (45), and may mirror more adequately the time dependent behavior of blood.

We all are acquainted with the excellent models, advanced by Fung, Bugliarello, Goldsmith and Mason, Skalak, Azuma, among others. There will also be a trend to propose new models which will characterize the rheological properties 
of biological systems and may come as close as possible to in vivo situations known to exist in different fields of the life sciences.

The relation between rheological properties and electrical phenomena is of great significance in the physiology of living matter. This has been emphasized in a number of publications by Geoffrey Seaman (46) and Don Brooks (47) and by Eiichi Fukada (48, 49).

The converse piezo-electric effect is, according to Fukada, the production of mechanical strain by applying an electrical field. Fukada considers piezoelectric relaxation together with comparative studies on elastic and dielectric relaxations of great importance in future research in biorheology (50). The clinical application of electric current to bone fracture has been successful in many patients (50). Fukada ascribes the osteostenosis of astronauts to the lack of electric activity in bone ( 50$)$.

The phenomenon of relief of pain by acupuncture or electrical stimulation or electromagnetic field stimulation is not well understood at present. The "gate control theory" and the concept of so-called "endorphins", i.e., endogenous morphine-like substances, have often been used to explain the relief of pain by these kinds of treatment. However, it was pointed out recently by Omura (51) that these concepts cannot explain many experimental and clinical findings associated with these forms of physical therapy.

I venture that there may be a new explanation which concerns biorheology. These physical treatments may produce alterations in the flow properties of cel1s or/and ce11 membranes at sites surrounding the inserted acupuncture needle or the applied electrode or electromagnetic field. The produced rheological changes may trigger the release of substances from these cells or their membranes, leading to an improved circulation of blood in the surrounding tissues and to the analgesic effect. Thus, the flow properties of blood may be affected as well, not merely in proximity to the site of treatment, but also in distant parts of the body, alleviatirg the pain also at such distant sites. Future research, employing specially developed instrumentation to measure such changes in flow properties of (a) the affected cells and $(b)$ the circulating blood may provide the needed information.

My friend Bun'ichi Tamamushi has done pioneer work on 1iquid crystals, mesophases or mesomorphic systems in relation to biorheology (52,53). Further exploration of this area appears to be highly promising.

As was recently emphasized by Somorjai (54), surfaces have been increasingly studied during the past fifteen years on the atomic scale. Although surface science had in recent years a rapid development with regard to the structure, bonding, and reactivity of many surface-adsorbate systems, very few inroads have been made pertaining to solid-liquid and solid-solid interfaces. This, however, is an area of great concern to biorheology. Maurice Joly pioneered on surface rheology $(5,55)$, a field which is of particular interest to me in connection with our studies made during the past decade on the rheology of surface layers of fibrinogen systems. Surface biorheology is expected to expand widely towards a better understanding of many crucial biological problems.

Quantum molecular methods were recently applied to structures and problems of biochemistry, particularly of large molecular systems (56,57). This led to the special fields of quantum biochemistry $(58,59)$ and a few years ago, to quantum pharmacology (59). The understanding of problems pertaining to molecular associations and conformations, in which, among others, hydrogen bonding, van der Waals forces and charge transfer are involved, are of great concern to many biorheological areas.

A crucial role is played by hydrogen bonding in the structure and function of many biological macromolecules. According to Pauling (60) the weakness of hydrogen bonds makes them ideal regulatory devices for biological reactions. There are numerous structural modifications known to occur with biopolymers, such as proteins and nucleic acids. It was pointed out recently by Geiger and Wagnière (61), that "since the discovery of the $\alpha-h e 1 i x$ in proteins and the double helix in nucleic acids, these molecules have also inspired theoretical studies of their electronic properties". According to these authors

the methods of calculation and adopted models have their roots in solid state physics and in traditional quantum chemistry. A new field of study, which could be designated as "quantum biorheology", may be expected which would combine the investigations of the optical activity. of large helical biopolymers, 
such as proteins and nucleic acids, with those employing biorheological treatments and techniques.

It was superbly demonstrated in living plant cells by Kamiya and associates and in hemorheological studies in vivo in animals and human subjects by Witte, Brånemark, Frasher, Wayland and Intaglietta that quantitation of certain observations could be accomplished with the highly sophisticated methods and technical procedures which these investigators so ingeniously developed. New developments can be expected in biorheological in vivo procedures for obtaining quantitative findings which will greatly advance our science.

As psychology is considered as belonging to the life sciences, the field of psychorheology, a term proposed by G.W. Scott Blair and F.M.V. Coppen (62), belongs to biorheology. Psychorheology together with other physical aspects and those of physiological nature will expand and offer many new tools towards a better understanding of the human psyche.

Biorheology with it numerous and multitudinous applications will become one of the major life sciences and be an integral part in the further development of human society.

In his Aharon Katchalsky Memorial Lecture at the First International Congress of Biorheology, the Convocation Chairman, who with this Congress will end his admirable tenure of six years as President of our society in two terms of office, aptly paraphrased "biorheology as 1ife, flow and deformation" (63).

Beyond doubt, I am too optimistic in suggesting that the differentiation between 1ife and inanimate matter may wel1 be decided by biorheological investigation and the perennial question what is life may thus find an answer.

It has become increasingly difficult to grasp the complexities in the manifestations and processes of life. Moreover, experimentation and interpretation of fundamental problems have opened vast new areas of complexities. Yet, the quest for posing questions, something we inherited from philosophy, can be wonderfully exhilarating as is to everyone alive the wonder of 1 ife. The study of life is an enterprise I have fallen into, seemingly, by chance. As each of us, I have experienced the urge to learn more about 1 ife as a student of biomedical sciences and in general.

In asking the question "What is Life?", perhaps we should be content with the metaphor Artistotle tried out in the seventh chapter of Book Lambda of the Metaphysics (64). He said: "The activity of thinking (energeia that has its end in itself) is life". Its inherent law is "unceasing motion, which is motion in a circle" (64).

A philosopher friend of mine, the late Hannah Arendt, stated in her recently post-humously published work 'The Life of the Mind' that "the thinking ego, whatever it may achieve, will never be able to reach reality qua reality or convince itself that anything actually exists and that 1ife, human 1ife, is more than a dream. This suspicion that life is but a dream is, of course, among the most characteristic traits of Asian philosophy; examples from Indian philosophy are numerous" (65).

Hannah Arendt (66) gave the following Chinese example: "It reports a story told about the Taoist (i.e., anti-Confucian) philosopher Chuang Tzu. He 'once dreamt he was a butterfly flitting and fluttering around, happy with himself and doing as he pleased. He didn't know he was Chuang Tzu (Chou). Suddenly he woke up and there he was, solid and unmistakable Chuang Tzu. But he didn't know if he was Chuang Tzu who had dreamt he was a butterfly, or a butterfly dreaming it was Chuang Tzu. Between Chuang Tzu and a butterfly there must be some distinction!"

To this delightful and very telling story I like to add: There must be some distinction between what is life and what it is not!

\section{In Conclusion}

I have attempted to set forth in simple language how I see the future of our science. As active biorheologists we are aware what it means to each of us to aim for far horizons. Here I should like to use a favorite citation of a composer friend of mine, the late Edgard Varèse. The citation is by Leonardo da Vinci who said: "Non si volta chi a stella a fisso". In a 1iteral translation by Varèse's widow Louise it says: "No one will turn back who is attached to a star" (67). Thank you very much. 


\section{RF,FFRENCFS}

1. RURGERS, J.M. et al (Eds). Proceedings of the International Congress on Rheology. Holland 1948. Amsterdam, North-Holland Publ. Co. 1949.

2. COPLEY, A.L. Rheological problems in biology. In: J.M. Burgers et al (1) Part I, General Lectures, pp. I-47 to T-61; Part ITI, Discussions, pp. ITT-8 to TIT-11.

3. SCOTT BLATR, G.W. Psychophysical aspects of rheology. In: J.M. Burgers et a1. (1) Part I, General Lectures, pp. I-95 to I-110.

4. ASTBURY, W.T. X-ray and electron microscope studies of the interaction of myosin and actin. Tn: J.M. Rurgers et al (1) Part II, Sectional Papers, pp. II-197 to II-201.

5. JOLY, M. Quelques propriétes de l'energie d'activation d'écoulement risqueux des couches monomoléculaires et leur interpretation structurale. In: J.M. Burgers (1) Part II Sectional Papers, pp. II-35 to II-43.

6. WEISSENBERG, K. Abnormal substances and abnormal phenomena of flow. In: J.M. Burgers et al (1) Part I, General Lectures, pp. I-29 to I-46.

7. WETSSENBERG, K. Specification of rheological phenomena by means of a rheogoniometer. In: J.M. Burgers et al (1) Part II, Sectional Papers, pp. II 114 to II-118.

8. KUHN, H. Hydrodynamic properties of randomly coiled long chain molecules as determined by experiments on large scale models. In: J.M. Burgers (1) Part I.I, Sectional Papers, pp. T.I-44 to T.T-57.

9. DE WAELE, A. and MARDLES, E.W.J. The rheology of suspensions. In: J.M. Burgers et a1 (1) Part II, Sectiona1 papers, pp. II-166 to II- 178 .

10. COPLFY, A.L. The rheology of blood. A survey. J. Colloid Sci. 7, 323-333, 1952.

11. SCOTT BLATR, G.W. Foreword. Tn: Flow Properties of Blood and Other Bio1 ogical Systems. A.L. Copley and G. Stainsby (Eds.) New York-Oxford-Lonतon, Pergamon Press. 1960, pp. XIII-XV.

12. FREY-WYSSLING, A. (Ed.) Deformation and Flow in Biological Systems. Amsterdam, North-Holland Publ. Co. 1952. $564 \mathrm{pp}$.

13. FREY-WYSSLING, A. (Ed.) Report on the 1. International Colloquium on Rheologica1 Problems in Bi.ology. 26.-28. July 1950, Lund, Sweden. Abstracts and Discussions. In: A. Frey-Wyssling (12), pp. $481-516$.

14. SCOTT BLAIR, G.W. The flow of blood in relation to the vessel wall. Nature (London), 182, 90-91, 1958.

15. SCOTT BLAIR, G.W. Flow properties of biological systems. Nature (London), 184, $1539-1540,1959$.

16. COPLEY, A.L. George W. Scott Blair, Co-Editor-in Chief (November 1959 to December 1978), Co-Founder of Biorheology - A tribute. Biorheology 15, this double issue $(5 / 6) 1978$.

17. COPLEY, A.L. (Ed.) Hemorheology. Proceedings of the First International Conference, The University of Iceland, Reykjavik, 1966. Oxford-LondonNew York, Pergamon Press. 1968, 871 pp.

18. COPLEY, A.L. Joint inaugural address. Biorheology as an organized science. Biorheology 10, 83-86, 1973.

19. COPLEY, A.I. On hiorheology. Joint plenary lecture. Biorheology 10, 87$105,1973$.

20. SFAMAN, G.V.F. and CHIEN, S. First international congress of biorheology. Federation Proceedings 32, 1645-1646, 1973.

21. COPLEY, A.L. (Ed.) Symposium on Biorheology. Proc. 4. Internat. Congr. 
Rheology, Providence R.T. 1963. New York-London, Tnterscience-John Wiley \& Sons $1965,645 \mathrm{pp}$.

22. FRASHER, W.G. and WAYLAND, H. Round table discussion on hemorheology. Biorheology 2, 55-59, 1964.

23. HARTERT, H.H. and COPLEY, A.L. (Eds.) Theoretical and Clinical Hemorheology. Berlin-Heidelberg-New York, Springer-Verlag, 1971, 426 pp.

24. COPLEY, A.L. and SCOTT BLATR, G.W. (Eds.) Proc. 1. Internat. Congr. Biorheology. Biorheology 9, 132-171, 1972; ibid. 10, 81-266, 1973; ibid.343-

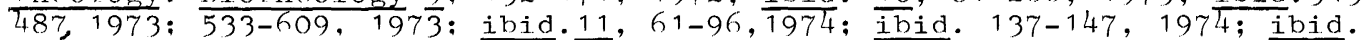
153-205. 1974; ibid. 279-511, 1974 ; ibid. 355-383, 1974; ibid. 457-471, 1974.

25. COPLEY, A.L. and JOLY, M. (Eds.) Proc. 2. Internat. Congr. Biorheology. Rehovot, Israel, 29.12.1974- 7.1. 1975. Biorheology 12, 81-109, 1975; ibid. 145-256, 1975; ibid. 257-282, 1975; ibid. 329-360, 1975; ibid. 13 , 1-81, 1976; ibid. 87-99, 1976; ibid. 151-164, 1976; ibid. 221-234, 1976; ibid. $273-28 \overline{0,1976 . ~}$

26. HUANG, C.R. and COPLEY, A.L. (Eds.) Internat. Symposium on Biorheology. Am. Inst. Chem. Engineers (AIChE), 70. Annual Meeting New York, 1977. New York, ATChE, 1978, in press.

27. COPLEY, A.L. and SCOTT BLAIR, G.W. Editorial. Reorganization of the journal of Biorheology. Biorheology 14, 215, 1977.

28. COPLEY, A.L. Aharon Katchalsky, 1914-1972. Biorheology 2, 127-129, 1972.

29. OKA, S. A theoretical approach to the effect of shear stress on the development of a theroma. In: Hemorheology and Thrombosis. A.L. Copley and S. Okamoto (Eds.). New York-Oxford, Pergamon Press. 1976, pp. 305-313; Thrombosis Research $\underline{8}$, Supp1. II, 305-313, 1976.

30. COPLEY, A.L. Hemorheology and Ischemia. In: 4. Koelner Symposium on Cerehra1 and Coronary Vascular Disorders and Infarcts. Max-Planck-Institut fuer Hirnforschung, Cologne, 21-24 June. 1978. Heidelberg-Berlin, Sprinrer-Verlag, in press.

31. FRY, D.L. Acute vascular endothelial changes associated with increased hlood velocity gradients. Circulation Res. 22, 165-197, 1968.

32. FRY, D. L . Certain histological and chemical responses of the vascular interface to acutely induced mechanical stress in the aorta of the dog. Circulation Res. 24, 93-108, 1969.

33. CARO, C.G. FITZ-GERALD, J.M. and SCHROTER, R.C. Arterial wall shear and distribution of early atheroma in man. Nature (London) 223, 1159-1161, 1969 .

34. CARO, C.G. FITZ-GERALD, J.M. and SCHROTER, R.C. Atheroma and arterial wall shear. Observation, correlation and proposal of a shear dependent mass transfer mechanism for atherogenesis, Proc. Roy. Soc. London, B 177, $109-159,1971$.

35. CARO. C.G. Transport of material between blood and'wall in arteries. A Ciba Foundation Symposium, 1972. In: Atherogenesis: Initiating Factors. R. Porter and J. Knight (Eds.). Amsterdam, Assoc. Sci. Pub1. 1973, pp. $127-164$.

36. COPLEY, A.L. Fibrinolysis and atherosclerosis. The Lancet i, 102-103, 1957.

37. COPLEY, A.L. A therosclerosis in a haemophiliac. The Lancet, ii, 1119-1120, 1957.

38. COPLEY, A.L. Non-Newtonian behavior of surface layers of human plasma protein systems and a new concept of the initiation of thrombosis. Biorheology 8, 79-84 1971.

39. COPLEY, A.L. and KING, R.G. Po1ymolecular 1ayers of fibrinogen systems 
and the genesis of thrombosis. Tn: Ilemorheology and Thrombosis. A.L. Copley and S. Okamoto (Fds.). Oxford-New York, Pergamon Press. 1976, pp. 393-408; Thrombosis Research 8, Supp1. II, 393-408, 1976.

40. COPLEY, A.L. and KING, R.G. The reducing action of highly purified $\gamma$ giohulin and $\beta$ lipoprotein on the viscous resistance of surface layers of fibrinogen. Thrombosis Research 4, 193-198, 1974.

41. MILLER, I.R., GRAET, H. and FREI, Y.F. Cholesterol exchange between surface 1 ayers and plasma proteins in bulk. A Ciba Foundation Symposium, 1972. In: Atherogenesis: Initiating Factors. R. Porter and J. Knight (Eds.). Amsterdam, Assoc. Sci. Publ. 1973, pp. 251-266.

42. SPANNER, D.C. Botanical aspects of biorheology. In: G.W. Scott Blair, An Introduction to Biorheology. Amsterdam-Oxford-New York, E1sevier Scient. Pub1. Co. 1974, Dp. 165-197.

43. POISEUILLE, J.L.M. Exnerimantal Investigations Upon the F1ow of Liquids in Tubes of Very Small. Diameter. (Translated by W.H. Herschel). Rheological Memoirs, vo1. 1, No. 1, Easton, Pa, E.C. Bingham, 1940.

44. POISEUILLE, J.L.M. Recherches sur 1es Causes du Mouvement du Sang dans 7 es Vaisseaux Capil laires. Acad. Sci., Séance publique du 28. dêcembre 1835. Tome VI des Savants étrangers. Paris, Impr. Royale. 1839.

45. HUANG, C.R., SISKOVIC, N., ROBERTSON, R.W., FABIASAK, W., SMTTHBERG, E.H. and COPLEY, A.L. Quantitative characterization of thixotropy of whole human b1ood. Biorheology 12, 279-282, 1975.

46. SEAMAN, G.V.F. The role of electrical charge in the stability and flow properties of red cell suspensions. In: Hemorheology, A.I. Copley (Ed.) $(17)$.

47. BROOKS, D.E. and SEAMAN, G.V.F. The effect of neutral polymers on the electrokinetic potential of cells and other charged particles. I. Models for the zeta potential increase. I. Coll. Interface Sci. 43, 670-686, 1973.

48. FUKADA E. Mechanical deformation and electrical polarization in biological substances. Biorheology 5, 199-208, 1968.

49. FUKADA, E. Piezoelectric properties of biological macromolecules. Adv. in Biophys. $\underline{6}, 121-155.1974$.

50. FUKADA, E, Persona1 communication, August, 1978.

51. OMURA, Y. Patho-physiology of acupunoture effects, ACTH and morphine-1ike substances, pain, phantom sensations (phantom pain, itch and coldness), brain microcirculation, and memory. Acupuncture and Flectrotherapeutic Research, Internat. J. 2, 1-31, 1976 .

52. TAMAMUSHT, B. Flow properties of smectic liquid crysta1s. Biorheology 10 , $239-247,1973$.

53. TAMAMUSHI, B. Colloid and surface chemical aspects of mesophases (liquid crystals). Pure \& Appl. Chem. 48, 441-447, 1977.

54. SOMORJAI, G.A. Surface science. Science 201, 489-497, 1978.

55. JOLY, M. Rheological properties of monomolecularfilms. In: Surface and Colloid Science, E. Matijevic (Ed.). New York, J. Wiley \& Sons. 1972, vo1. 5, pp.1-193.

56. SCHERAGA, H.A. Calculations of conformations of polypeptides. Adv. Phys. Org. Chem. 6, 103-184, 1968.

57. SZENT-GYORGYI, A. Introduction to a Submolecular Biology. New York, Academic Press. 1960.

58. PULLMAN, A. and PULLLAN, B. Quantum biochemistry. In: Comprehensive Biochemistry. M. Florkin and E.H. Stotz (Eds.). Amsterdam-New York, Elsevier Scient. Publ. Co. 1967, vo1. 22, pp. 1-60.

BRY, $155 / 6 \quad$ C 
59. PULLMAN, A. and PULLMAN, B. Quantum biochemistry. In: Wave Mechanics. The First Fifty Years. W.C. Price, S.S. Chissick and T. Ravensdale (Eds.) London,Butterworths. 1973, pp. 272-291.

60. PAULING, L. The Nature of the Chemical Bond. Ithaca, NY, Cornell University Press. 1960.

61. GEIGER, R.E. and WAGNIÈRE, G.H. Application of wave mechanics to the study of natural optical activity in organic molecules. In: Wave Mechanics. The First Fifty Years. W.C. Price, S.S. Chissick and T. Ravensdale (Eds.) London, Butterworths. 1973, pp. 292-314.

62. SCOTT BLAIR, G.W. An Introduction to Biology. Amsterdam-Oxford-New York, El sevier Scient. Pub1. Co. 1974, 228 pp.

63. SILBERBERG, A. The Aharon Katchalsky Memorial Lecture: Life, flow and deformation. Biorheology 10, 109-116, 1973.

64. ARISTOTLE. Metaphysics. In: Hannah Arendt (65), reference 125, p. 243.

65. ARENDT, H. The Life of the Mind. Vo1. 1, Thinking. New York and London, Harcourt Brace Jovanovich, 1978. pp. 123-124.

66. ARENDT, H. Tbid. (65), p. 198.

67. VARESE, L. Personal communication. August 1978. 